\title{
UNIFORMITY IN FINANCIAL ACCOUNTING: A PROGRESS REPORT
}

\author{
Thomas D. FlynN*
}

If a stranger to the subjects of uniformity, comparability, diversity, and flexibility in accounting principles and in financial statements were to find himself in the midst of a discussion of these important topics, he might turn to his dictionary for enlightenment. Having read the definitions he might turn away mystified. Indeed, he might well conclude that he had misunderstood the key words-that the discussion had really been about something else.

Not a few accountants, participating again and again in such discussions, themselves turn away mystified, for a substantial part of the disagreement on the complicated issues that bear the deceptively simple labels of "uniformity" and "comparability" on the one hand and "flexibility" and "diversity" on the other lies in the diverse interpretations of these words in the minds of the disputants and in the emotions the words evoke.

\section{I}

\section{Begrnnings}

The roots of the problem go back a good many years-perhaps as far back as the history of accounting itself. We may meaningfully pick up the thread, however, in the early r 930 s. This period produced several major developments which were to have important effects on accounting thought. One was an exchange of correspondence between committees of the American Institute of Accountants [now the American Institute of Certified Public Accountants (AICPA)] and the New York Stock Exchange.

The committees addressed themselves to problems believed to have arisen because of variations in the accounting methods in use by listed companies. The following excerpt from a letter written by the Institute's Special Committee on Cooperation with Stock Exchanges expresses the Committee's view as to a solution:

In considering ways of improving the existing situation two alternatives suggest themselves. The first is the selection by competent authority out of the body of acceptable methods in vogue today of detailed sets of rules which would become binding on all corporations of a given class. This procedure has been applied broadly to the railroads and other regulated utilities, though even such classifications as, for instance, that prescribed by the Interstate Commerce Commission allow some choice of method to corporations governed thereby. The arguments against any

*A.B. 1935, Princeton University; M.A. I939, Columbia University. Partner, Arthur Young \& Co.; President, American Institute of Certified Public Accountants, I964-65. 
attempt to apply this alternative to industrial corporations generally are, however, overwhelming.

The more practicable alternative would be to leave every corporation free to choose its own methods of accounting within the very broad limits to which reference has been made, but require disclosure of the methods employed and consistency in their application from year to year. It is significant that Congress in the federal income-tax law has definitely adopted this alternative, every act since that of $19 \mathrm{r} 8$ having contained a provision that the net income shall be computed "in accordance with the method of accounting regularly employed in keeping the books of such taxpayer" unless such method does not clearly reflect income. In its regulations the Internal Revenue Bureau has said, "the law contemplates that each taxpayer shall adopt such forms and systems of accounting as are in his judgment best suited to his purpose." ... The greatest value of classifications such as those imposed on regulated utilities lies in the disclosure of method and consistency of method which they tend to produce.

Within quite wide limits, it is relatively unimportant to the investor that precise rules or conventions are adopted by a corporation in reporting its earnings if he knows what method is being followed and is assured that it is followed consistently from year to year. Reverting to the illustrations already used, the investor would not need to be greatly concerned whether the straight-line or the sinking-fund method of providing for depreciation were being employed by a given corporation, provided he knew which method was being used and knew that it was being applied in the same way every year. But if depreciation is charged in one year on the straight-line basis applied to cost and in another is charged on a sinking-fund basis applied to a valuation less than cost, the investor may be grossly deceived unless the change is brought to his notice. For this reason, the requirement of the Exchange that the depreciation policy of a company applying for listing shall be stated in the application is valuable, and it might well be amplified to include an undertaking to report to the Exchange and to stockholders any change of policy or any material change in the manner of its application. ${ }^{1}$

Departing for a moment from the historical frame of reference, it is essential to point out that things have changed since the r930s. While it may then have been unimportant to the investor to know "what precise rules or conventions are adopted," variations in accounting principles have since taken on far greater sig. nificance. As a result of continued broadening of the interest in investment opportunities, there are now some 20,000,000 Americans who own shares in publiclyowned companies. As a result, financial statements have come to be used more and more in attempts to compare the operating results and financial position of one company with those of another or others.

Let us return now to the situation in I932. Under the approach proposed by the Institute committee and adopted by the Exchange committee, each corporation was to remain free to choose its accounting practices, within the framework of certain broad standards. In furtherance of this intent, the form of report used by auditors

\footnotetext{
${ }^{1}$ American Instrtute of Accountants, Audits of Corporate Accounts 7-8 (1934) [the Amcrican Institute of Accountants is hereinafter cited as AIA].
} 
was to be changed. The auditor was to state whether the practices followed conformed to certain broad principles and whether they had been consistently applied.

To meet the need for a reference point in this form of report, the expression "accepted principles of accounting" was chosen. Within a few years this became the expression "generally accepted accounting principles," which has continued in use in auditors' reports down to the present time.

The accounting profession and the exchange were not the only groups to recognize a need for improvement in the reporting practices of publicly-owned companies. The Congress of the United States evidenced its concern by the enactment of the Securities Act of $1933^{2}$ and the Securities Exchange Act of $1934^{3}$ The latter established the Securities and Exchange Commission, and the former gave it the power by law to prescribe accounting rules for use in financial statements filed with the Commission. ${ }^{4}$ The Commission has been a potent force, but by and large it has chosen not to prescribe accounting principles. Instead it has relied heavily on the accounting profession and on the corporate officers having primary responsibility for the financial statements filed with it. ${ }^{5}$

In the mid-r930s, still another group expressed renewed interest in accounting principles. In 1936 the American Accounting Association (which in 1935 had changed its name from the American Association of University Instructors in Accounting) issued A Tentative Statement of Accounting Principles Underlying Corporate Financial Statements. This statement was not intended as an authoritative definition of "generally accepted accounting principles." Rather, it "attempted to set forth some of the bases upon which accounting statements rest." The Association's active participation in the development of accounting principles has continued. The I936 statement has since been revised, and a number of supplemental statements have been issued.

By the late I930s it had become evident to many that variations in accounting practices, under the umbrella of generally accepted accounting principles, were too numerous. The 1938 report to the Institute's Council of the Committee on Accounting Procedure presented the issues clearly. On the one hand, the report stated the continuing concern for uniformity; on the other, it recognized a problem that has persisted to this day-the need for a satisfactory definition of "uniformity," as applied to accounting principles. The following extracts are pertinent:

The committee on accounting procedure, recognizing the existence of a widespread demand for greater uniformity in accounting, has given continuous consideration to the question how progress in the desired direction could most wisely be made. It feels that any such effort should, as far as possible, be coordinated with similar activities of regulating bodies, such as those of the Securities and Exchange

\footnotetext{
${ }_{4}^{2} 8$ Stat. 74 , as amended, ${ }_{5}$ U.S.C. $\$ \$ 77 \mathrm{a}-\mathrm{aa}$ (1964).

${ }^{3} 48$ Stat. $88 \mathrm{I}$, as amended, I5 U.S.C. $\$ \$ 78 \mathrm{a}-\mathrm{hh}(\mathrm{ig} 64)$.

"Section 19 (a), 48 Stat. 85 , as amended, I5 U.S.C. $\$ 77 \mathrm{~s}$ (a) $\left(x_{964}\right)$.

'See Pines, The Securities and Exchange Commission and Accounting Principles, infra, pp. 727-5I.
} 
Commission, and with the work of the teachers of accounting. It feels also that there is much to be done in the way of clearing the ground before any permanently valuable structure can be created, and it has given much thought to the question how this preliminary work can best be accomplished.

First, it is necessary to determine what is meant by uniformity. Some assume that definite and uniform rules could be laid down for the treatment of every conceivable transaction, leaving to judgment only the determination of the class into which a particular transaction falls. However, practically every so-called uniform classification permits alternative treatment of certain items and permits, also, a departure from the established procedure in special cases. The committee believes, also, that the relation of the problem of uniformity to the problem of adapting accounts to the different purposes for which they are legitimately required calls for more extensive consideration than it has hitherto received. ${ }^{6}$

The report also proposed a course of action:

[T] he Institute should create, under the control of a somewhat enlarged committee on accounting procedure, a research department for the purpose of preparing studies on particular questions, distributing them in such a way as the committee might deem expedient, and ultimately formulating rules on specific points which would be binding on the members of the Institute unless and until adverse action upon them should be taken, either by the council of the Institute or the membership at large. ${ }^{7}$

The essence of the proposals was adopted. The Committee's membership was forthwith increased from seven to twenty-one, and in I939 the Institute established a research department. The authority of the Committee, however, took a somewhat different form than that proposed. The Committee's Accounting Research Bulletins have not been binding on the members of the Institute. Rather, the authority of the Bulletins has rested on their general acceptability. In r94 the Committee issued the first in its series of Accounting Research Bulletins, which were to number fiftyone during the lifetime of the Committee.

In determining the direction it should take in issuing bulletins, the Committee chose an avenue which may be termed "practical" and "piecemeal," whereas it might have chosen a more long-range route labeled "theoretical" and "comprehensive." That is, the Committee chose in its Bulletins to deal with specific problems that required attention from time to time, rather than to attempt to create an entire fabric of principles. Partly for this reason, the issue of uniformity, in the sense that would have required the development of a comprehensive statement of accounting principles, fell somewhat into the background. Although there were varying degrees of interest in the subject from time to time, it was almost twenty years before the question of uniformity (by then transmuted into comparability of financial statements) again became a crucial issue.

\footnotetext{
- Commitee on Accounting Procedure, AIA, Report (1938), reprinted in AIA, 1938 Yearbook $x 16$. ${ }^{7}$ Ibid.
} 


\section{A Change in Approach-The Accounting Principles Board}

By 1957 many accountants had become convinced that the Institute's approach to the development of accounting principles was in need of change. A new organization of the Institute-an eighteen-member Accounting Principles Board (the membership was later increased to twenty-one and is now to be reduced again to eighteen)replaced the Committee on Accounting Procedure, and an expanded Institute research arm-the Accounting Research Division—came into being.

\section{A. The Board's Mission}

One of the principal missions of the new Board (APB) was to provide the longawaited over-all statement of accounting fundamentals. This was expressed as follows in a report issued in 1958 by a committee whose recommendations led to the creation of the Board and the new Research Division:

The general purpose of the Institute in the field of financial accounting should be to advance the written expression of what constitutes generally accepted accounting principles for the guidance of its members and of others. This means something more than a survey of existing practice. It means continuing effort to determine appropriate practice and to narrow the areas of difference and inconsistency in practice. In accomplishing this, reliance should be placed on persuasion rather than on compulsion. The Institute, however, can, and it should, take definite steps to lead in the thinking on unsettled and controversial issues.

The broad problem of financial accounting should be visualized as requiring attention at four levels: first, postulates; second, principles; third, rules or other guides for the application of principles in specific situations; and fourth, research.

Postulates are few in number and are the basic assumptions on which principles rest. They necessarily are derived from the economic and political environment and from the modes of thought and customs of all segments of the business community. The profession, however, should make clear its understanding and interpretation of what they are, to provide a meaningful foundation for the formulation of principles and the development of rules or other guides for the application of principles in specific situations. Also, the Institute should encourage co-operative study with other representative groups to determine that its understanding and interpretation of the postulates are valid and to provide a forum which will command sufficient respect to bring about a change in the postulates when any of them become outmoded.

A fairly broad set of co-ordinated accounting principles should be formulated on the basis of the postulates. The statement of this probably should be similar in scope to the statements on accounting and reporting standards issued by the American Accounting Association. The principles, together with the postulates, should serve as a framework of reference for the solution of detailed problems.

Rules or other guides for the application of accounting principles in specific situations, then, should be developed in relation to the postulates and principles previously expressed. Statements of these probably should be comparable as to 
subject matter with the present accounting research bulletins. They should have reasonable flexibility. ${ }^{8}$

Efforts to carry out the Board's broad mission-to provide a definition of generally accepted accounting principles have focused renewed attention on old, unanswered questions. The Accounting Principles Board, in deliberating on matters of accounting principle, and the Accounting Research Division, in probing into areas designated for research, have encountered a multiplicity of such issues, the solutions of which are interdependent one upon the other. Among the questions: What purposes do financial statements serve? To whom are they directed? To what extent is the existence of alternative practices compatible with the notion of accounting uniformity? Can financial statements of highly dissimilar companies be comparable, however uniform the accounting principles used?

In Ig6o, Carman Blough stated the issue as follows:

Some seem to believe that uniformity of accounting principles and procedures is what is most needed; that rules should be established in such detail that similar transactions would always be handled similarly in the accounts. Comparability is their goal. Others believe that such uniformity would be impossible but firmly believe that much more uniformity than we now have would not only be possible but highly desirable. Still others consider uniformity to be highly dangerous. To them, subjective judgment in each case should govern; they believe consistency, accompanied by disclosure, is of primary importance. ${ }^{9}$

\section{B. The Investment Credit Debate}

The enactment by the Congress of the investment tax credit in $1962^{10}$ triggered a chain of events that made accountants painfully aware of the differences of opinion.

In December 1962, the Accounting Principles Board, by the required two-thirds vote, adopted its Opinion No. 2 expressing the view that the investment credit should be taken into income over the life of the related assets (the "spread" method). ${ }^{11}$ But some practitioners, including some members of the Board, and some other businessmen felt that forty-eight per cent of the investment credit should be viewed as a tax windfall, to be taken into income in the year assets were purchased (the " $48-52$ flowthrough" method); the remaining fifty-two per cent was to be spread over the life of the assets to recognize the reduction in the basis for determining depreciation. Many who agreed with the Board that the spread method was preferable disagreed

\footnotetext{
${ }^{a}$ Special Comm. on Research Program, AiCPa, Report to Council (1958), reprinted in J. Accountancy, Dec. 1958, pp. 62-63.

${ }^{-}$Blough, Accounting Research for Better Financial Reporting, in TwentY-Second ANNuAd INSTITUTE on Accounting, Proceedings (Ohio State University, 1960).

${ }^{10}$ INT. REv. CODE of I954, $\$ 38$, as amended, Revenue Act of 1962, $\$$ I (a), 76 Stat. 960 .

${ }^{11}$ Accounting Principles Bonrd, AICPA, Accounting for the "InvestMent Credit" (Opinion No. 2, 1963 ).
} 
with the Board's conclusion that there should be but a single acceptable accounting treatment of the investment credit.

Shortly after the Board issued its opinion, two unusual actions made it clear that the position of the APB in the development of generally accepted accounting principles-and indeed the position of the AICPA itself-needed to be clarified. First, certain accounting firms let it be known that they would not insist that their clients use the method the Board had approved. Second, the SEC reported that in recognition of the substantial diversity of opinion the Commission would accept financial statements in which the credit was accounted for by either of the two methods described above. ${ }^{12}$

Widespread discussion followed upon these developments, and the Board again considered the matter in early 1964 , when it issued a new opinion (No. 4) amending its position on accounting for the investment credit. ${ }^{13}$ Taking note of the action of the SEC in accepting the flow-through method and the use of that method by an increasing number of companies, the Board in the new opinion stated that it now considered two methods (the flow-through method and the spread method originally favored by the Board) to be acceptable. Several members of the Board dissented, pointing out that both methods could not be right.

As an accounting problem, the investment credit was not of fundamental importance. The real significance of the debate was that it focused broad attention on such basic questions as these: What is meant by the term "generally accepted accounting principles"? What is, and what should be, the authority of the Accounting Principles Board? How can the Board best move to narrow areas of difference in accounting?

\section{A Step Toward Increased Comparability}

Thus the issue of comparability of financial statements of different companies was joined with the issue of the authority of opinions of the Accounting Principles Board.

It is axiomatic that the independent public accountant's basic function-attesting to financial representations of others-rests, in part, on the existence of a measuring stick (generally accepted accounting principles) against which the financial representation being examined can be evaluated and compared. The reliance that investors and others place on the CPA's opinion implies responsibility on the part of CPAs to take a leading role in identifying and improving generally accepted accounting principles.

In October I964, the Council of the AICPA took an important step grounded on recognition of this responsibility. Under the Council action, which will take effect

\footnotetext{
${ }^{13}$ SEC Accounting Ser. Release No. 96, Jan. 10, 2963.

${ }^{10}$ Accounting Principles Board, AicPa, Accounting for the "Investment Credit" (Opinion No. 4, 1964) (amending Opinion No. 2).
} 
as to financial statements for periods beginning after December 31,1965 , members of the AICPA must arrange for the disclosure of any material deviations between accounting principles used in financial statements on which they report and principles accepted by the Accounting Principles Board. ${ }^{14}$ Disclosure may be made either in notes to the financial statements or in the accompanying auditors' report. Where practicable, the effect of the departure, as well as the fact of the departure, is to be disclosed.

The disclosure action stops short of saying that endorsement by the Board is the only criterion of general acceptance of an accounting principle. If the auditor believes that a practice followed by a client has other substantial authoritative support, even though not accepted by the Board, he may give an unqualified opinion on the financial statements, while seeing to it that attention is called to the departure. The expectation, of course, is that the requirement to disclose deviations from an identifiable standard-opinions of the Board and Accounting Research Bulletins issued by the predecessor Committee on Accounting Procedure-will lead to greater conformity with the standard and to consequent improvement in the usefulness of financial statements.

In adopting the disclosure requirement, it is clear that the AICPA has taken a step in the direction of improved comparability. Whether the Institute succeeds in this objective will be judged in retrospect largely by the quality and applicability of the opinions issued by the Accounting Principles Board.

\section{III}

\section{Opposing VIEWS}

In no small degree, the failure of CPAs to arrive at a satisfactory definition of the goal of uniformity has resulted because emotional factors have seemed invariably to enter the discussions. Reed K. Storey, appraising Carman Blough's comment on the uniformity issue (quoted above), wrote,

If this description carries just a hint of extremism, it accurately reflects the fact that extremism has almost always been a characteristic of accountants' discussions of uniformity. Even recently, many proponents of more comparability have charged their opponents with recommending complete and uninhibited freedom on the part of companies and their accountants to choose any procedure they please. Their opponents imply that comparability in accounting must be identified with the type of accounting and reporting systems prescribed for railroads, public utilities, and other regulated companies by various state and Federal regulatory agencies. The one group has been charged with being concerned only with the desires of the client company and the protection of the accountant; the other has been criticized for trying to encase accounting in a straitjacket of rules which would stifle all change and progress. Needless to say, the tendency of each group to characterize members

14 AICPA, Disclosure of Departures from Opinions of the Accounting Principles Boatro (Special Bull., $\mathrm{I}_{96}$ ). 
of the other as fools or knaves has not provided a solid basis on which to establish a settlement of differences. ${ }^{15}$

More recently, the opposing views were juxtaposed in a research study commissioned by the AICPA-Paul Grady's Inventory of Generally Accepted Accounting Principles for Business Enterprises. In the study, Mr. Grady proposed a number of "basic concepts to which accounting principles are oriented." Among these was one that may properly be characterized as the antithesis of uniformity: "Diversity in Accounting Among Independent Entities." This concept is closely related to the concept of flexibility, but focuses attention on the existence of differences rather than on the choice of methods.

In support of the concept of "diversity" (flexibility), Mr. Grady cited the three paragraphs quoted above ${ }^{\mathbf{1 6}}$ from the r932 letter of the AICPA Special Committee on Cooperation with Stock Exchanges to the Committee on Stock List of the New York Stock Exchange. He then wrote the following:

It is evident from the foregoing that the joint undertaking for improvement in financial reporting between the Institute and the New York Stock Exchange, which as previously noted created the concept of consistency in accounting between periods for the same entity, recognized and deliberately did not change the previously existing concept that there is diversity in accounting as among separate independent entities. The judgment of the special committee of the Institute and Committee on Stock List of the New York Stock Exchange in rejecting an attempt to bring about uniformity in accounting, was corroborated in a publication "Reports to Stockholders" by the Business and Planning Council for the Department of Commerce in 1934 and, also, in A Statement of Accounting Principles by Sanders, Hatfield, and Moore, published in 1938 .

The Accounting Research Bulletins issued by the committee on accounting procedure during most of its existence recognized the concept of diversity among separate entities, many of them having set forth alternate choices in accounting treatments to be exercised by management with appropriate disclosure. In a recent Opinion, Number 4, the Accounting Principles Board has approved an alternate method of accounting for the investment tax credit, although it expressed a preference for the method it had previously recommended, exclusively, in Opinion Number 2. Thus members of the Board, in common with most experienced accountants, recognize that diversity in accounting among independent business entities is a basic fact of life.

There is a minority view which urges uniformity in accounting as the panacea for all accounting and reporting deficiencies. The following pertinent factors indicate the unreality of such suggestions or expectations:

I. Judgment and estimates play a substantial role in accounting on an accrual basis, which is the only useful basis for presenting statements of financial position and results of operations for complex business entities. It is axiomatic that when

\footnotetext{
${ }^{16}$ Reed K. Storey, The Search for Accounting Princtples 54 (I964).

${ }^{10}$ See text accompanying note I supra.
} 
there is diffusion in decision-making, a necessity to the free enterprise system, there is bound to be diversity in the accounting results.

2. Each business entity must follow generally accepted accounting principles, i.e., those which have substantial authoritative support, in order to obtain an unqualified opinion from the certified public accountant. However, ... there are rather numerous alternative methods of applying such principles, and it is not possible, short of government fiat, to prescribe a one and only method. Under the circumstances, it is inconsistent and impossible of performance to expect the management of an entity to (a) choose the accounting practices and methods of application most suitable to the needs and purposes of the entity and which, in the judgment of management, will most fairly present the financial position and results of operations, and (b) at the same time, follow accounting practices and methods of application which are "uniform" with other business entities.

3. The attainment of a substantial degree of uniformity would require the preparation and adoption of a comprehensive manual prescribing a uniform code of accounts, with full directions as to the items to be charged and credited to each account, directions as to elements of cost to be included in fixed assets including direct costs and overheads, catalogue of property units, directions as to elements of cost to be included in inventories and how to determine market values, prescription of whether Lifo, Fifo or average cost is to be followed, detailed instructions on allocation of costs between periods including methods and rates of depreciation by classes of property and innumerable other instructions.

4. It is obvious that no single manual of instructions would fit the needs of all industry. Therefore, the broadest possible approach would be to prepare suggested uniform systems for each type of industry. Such systems have been developed for certain industries, but most of the companies in such industries find it necessary to develop their own systems to fulfill better their particular requirements for management information and control.

5. Even in those industries, such as railroads, communications, electric and gas, where the companies follow prescribed uniform systems, diversity in accounting is not and cannot be eliminated. As previously stated, judgment and estimates play a substantial role in accounting and where there is diffusion in decision-making there is bound to be diversity in the accounting results. Another reason for diversity in the accounting for regulated industries is the substantial influence of the ratemaking policies followed by various federal and state commissions on the timing of cost allowances. The diversity in rate-making decisions regarding allowance for income taxes, for example, is the cause of the diversity in accounting by public utilities as represented by the "flow-through" method and the "normalization" or deferred tax methods of treating the income tax effect of accelerated depreciation.

Recognition of the concept of diversity in accounting among independent entities, as a fact of business life, in no way imperils the objective of the Accounting Principles Board to "narrow the areas of difference in accounting" and to promote continuous improvement and greater comparability in financial statements. It does, however, place the objective within realistic limits which fall considerably short of uniformity. ${ }^{17}$

\footnotetext{
${ }^{17}$ PaUl Grady, Inventory of Generally Accepted Accounting Principles for Bustness EnterPRISES 33-34 (AICPA Accounting Research Study No. 7, 1965).
} 
Of course, the choice of viewpoints is not limited to one of either total diversity or total uniformity. As might be expected, there is a tremendous range of positions in between these two extremes. Thomas J. Cogan, another member of the Project Advisory Committee assigned to this study, points this out in the following comment:

The Inventory goes on to conclude that diversity in accounting is "a basic fact of business life," and then refers to a minority view which urges uniformity indicating that this is regarded as a "panacea."

This discussion, as it stands, appears to be a statement of the problem of diverse accounting in terms of two extremes-the diversity which existed in 1932 versus a degree of uniformity which would extend into all details of accounting determinations.

In my opinion, the Inventory should have pointed out that there is a substantial body of accountants, and others possessing interest in financial statements, which believes that diversity to the extent possibly deemed acceptable in 1934 is clearly undesirable under present conditions if accounting is to function effectively as a means of communicating financial information. This group does not propose that the determination of accounting policies by reporting entities should be put into a straitjacket of uniformity such as would be represented by the degree of detail referred to in the Inventory. It does believe, however, that corporate managements must accept some discipline in their choice of accounting principles and that alternatives stemming from conclusions that are logically incompatible when applied to the same set of facts, should be done away with or, in any event, kept at a minimum. While the Inventory may have intended to recognize this view when it referred to placing within realistic limits the efforts of the Accounting Principles Board's effort to narrow areas of differences in accounting, it has not, I believe, made the point clear $\ldots .^{18}$

\section{The Continuing Problem}

\section{A. Its Complexity}

Thus, the clash of views continues, as it must be expected to continue in the foreseeable future. That the problem has not been resolved is due largely to its immense complexity. Consider, for example, the complexities in delineating the accounting procedure to apply when two companies combine in a transaction involving issuance of capital shares by the company which continues. It is difficult enough to reach agreement as to the conditions which if present should make one transaction a "purchase," another a "pooling of interests." Further difficulties arise, however, in deciding particular cases; whatever criteria are adopted, few transactions will match them point for point. Put another way, there is no black and no white, only shades of gray. Or, consider the problems in determining depreciation or in deciding whether to defer research and development expenditures. A wide range of

\footnotetext{
${ }^{18} I d$. at $437-38$.
} 
circumstances must be considered in resolving such questions; it is unlikely that all will point toward the same decision. Again, we have only shades of gray.

American business exhibits a staggering variety of forms, arrangements, and kinds of transactions and events. And it continues to become increasingly complex. The accounting for all these businesses must be in accordance with accounting principles that express and measure, with reasonable accuracy, these complexities. It has been said that accounting can rise no higher in the scale of certainty than the events that it reflects. For the sake of simplicity and uniformity we cannot cram accounting into molds wholly unsuited to the facts. If we did, accounting would no longer be the language of business. It would no longer describe real, living business organisms.

This does not mean, however, that there should be no standards, that nothing can be done to promote greater uniformity. What we are really talking about is the relative degree of uniformity we should seek.

Some in the investment and financial community seem to feel that uniformity should be absolute and universal; that if this were acknowledged, much of the debate over alternative accounting principles would lose its force, and solutions to a number of problems could be reached rapidly. One view is that it does not matter which accounting principles are selected and agreed upon, so long as they are uniform for all businesses and are consistently applied over a long period.

The vast majority of CPAs and corporate management, of course, are united in their opposition to such an idea. Few CPAs, even those who are most extreme in their criticisms of the present diversity of accounting principles, would abandon what they regard as a better accounting principle, and accept a less satisfactory alternative, merely to attain uniformity.

\section{B. A New Definition and Some New Questions}

Alvin R. Jennings, a former chairman of the Accounting Principles Board, has proposed an objective that offers hope of a solution. He has said, "The need is not for uniformity without regard to circumstances. Rather, it is the elimination of variations [in accounting principles] which cannot be justified by differences in circumstances ...."19 I endorse Mr. Jennings' statement as a workable definition of accounting uniformity, but it does not end the need for definitions. The question now becomes: What do we mean by "differences in circumstances"? Does this expression encompass differences in the degree of management optimism or differences in financing policy (for example, retention of earnings versus borrowing)?

A special AICPA committee to review the operations of the Accounting Principles Board recommended to the Institute's Council in May rg65 that the Board recognize an objective paralleling that advanced by Mr. Jennings. ${ }^{20}$ The recom-

\footnotetext{
${ }^{19}$ Jennings, Opinions of the Accounting Principles Board, J. Accountancy, Aug. 1964, p. 27, at $3 \mathrm{r}$.

${ }^{20}$ Special Comm. on Opinions of the Accounting Principles Board, AICPA, Report (1965).
} 
mendation was referred to the Board, and in September I965 the Board reported as follows:

One of the key items in the Special Committee's report is a recommendation that the Board should move toward the reduction of alternative practices by adopting policies which would confine variations to those justified by substantial differences in factual circumstances, give criteria for application of acceptable variations, and where alternatives are justified, state the preferred treatment and require disclosure. The Board heartily endorses these proposals as important objectives, and will most assuredly keep them in mind in preparing future Opinions. In all fairness to the Board and the accounting profession generally, however, the Board believes it should point out that the circumstances surrounding specific pronouncements, and quite frequently the nature of the subject matter with which they deal, may preclude literal compliance with these objectives at times. Quite frankly, the Board needs further time for experimentation with this recommendation in a variety of situations before it can respond on an informed basis with respect to its applicability in specific instances. We hope that the exceptions to its application will not be frequent. ${ }^{21}$

\section{Cooperation with Industry}

A development of the past year that I find encouraging is the increased participation by representatives of industry in the process of improving accounting principles. I have been particularly pleased with the interest and cooperation of the Financial Executives Institute, one of the most powerful and influential of the industry groups. During the year the FEI decided to step up its efforts substantially in the area of accounting principles research. Its Accounting Committee will be provided with full-time staff, and the Committee will attempt to reach a consensus on drafts of accounting research studies and opinions issued by the APB.

This is something that the Financial Executives Institute has never before attempted. Previously, the members of its Accounting Committee spoke separately as individuals, with no effort made to speak for the Committee as a whole. The decision of the FEI to reach a consensus will give the views of its members much more weight. The Committee intends to support its conclusions with well-reasoned arguments covering all the major points involved.

We should recognize that the various industry groups have not been organized to deal effectively with the many accounting problems for which satisfactory answers have not yet been found. We have to expect that it will be some time before they will be organized to discharge their responsibilities fully. In the meantime, we in the Institute must have extra patience, and lean forward, not backwards, in our efforts to cooperate with them. It must be remembered how much effort and time has gone into organizing the Accounting Principles Board so that it can be truly effective and that in building our APB structure and research effort we had a considerable head start in the work of the old Accounting Procedures Committee.

\footnotetext{
${ }^{31}$ Id, at 8 .
} 
$\mathrm{V}$

FOR THE FUTURE

The road has been long, and the end is not in sight. Recent developments, however, point toward measured progress. The issues are vast and complex, and their impact on Amercian business is far-reaching. The success of the AICPA in securing the active participation and cooperation of industry groups and other organizations having an interest in accounting principles is an encouraging sign.

It is clear that economic growth and the continued broadening of participation in that growth depend importantly on an informed investing public. Making financial statements as useful as possible in informing the investing public will require further steps toward accounting uniformity, with resultant improvements in the comparability of financial statements. Programs now in progress, if patiently and persistently pursued, will result in steady progress toward that goal. 